\title{
HPLC for Confirmatory Diagnosis and Biochemical Monitoring of Cuban Patients with Hyperphenylalaninemias
}

\author{
Jiovanna Contreras MS, Elsa Alonso, Lisset E. Fuentes
}

\begin{abstract}
INTRODUCTION Hyperphenylalaninemias are inborn errors of phenylalanine metabolism caused by deficiency of L-phenylalanine hydroxylase (the enzyme that converts phenylalanine to tyrosine), resulting in increased serum phenylalanine ( $>4 \mathrm{mg} / \mathrm{dL}$ or $240 \mu \mathrm{mol} / \mathrm{L}$ ). Phenylketonuria, or PKU, is the most common form. Untreated PKU is associated with progressive neurodevelopmental delay, evolving towards intellectual impairment.
\end{abstract}

Cuba introduced a national newborn screening program for PKU in 1986. It has enabled early diagnosis and initiation of dietary treatment, reducing appearance of intellectual impairment in these patients. Originally, confirmatory diagnosis was done only by quantifying serum phenylalanine. In 2010, however, an HPLC method for quantifying serum phenylalanine and tyrosine simultaneously was validated at the National Medical Genetics Center, to perform confirmatory and differential diagnosis of hyperphenylalaninemias, as well as biochemical monitoring of patients diagnosed.

OBJECTIVES Describe experience using HPLC confirmatory diagnosis for positive cases from the National Neonatal Screening Program for Phenylketonuria and in biochemical monitoring of diagnosed patients after initiation of dietary treatment.

METHODS A descriptive retrospective case-series study was conducted from June 2010 through June 2012. The study population comprised 531 infants who tested positive in the National Neonatal Screening Program for Phenylketonuria. Variables used were serum phenylalanine concentration (first criterion of positivity) and tyrosine, phenylalanine/tyrosine ratio (second criterion, both detected by

\section{INTRODUCTION}

Hyperphenylalaninemias (HPA) are inborn errors of metabolism of the amino acid phenylalanine (Phe), caused in $98 \%$ of cases by mutations in the gene encoding the enzyme L-phenylalanine hydroxylase (PAH) (EC 1.14.16.1), which is responsible for converting Phe into tyrosine (Tyr) by hydroxylation.[1-5] The remaining $1 \%-2 \%$ of cases are attributable to defects in other enzymes involved in synthesis or regeneration of tetrahydrobiopterin (BH4), the natural cofactor for $\mathrm{PAH}$, tyrosine 3-hydroxylase and tryptophan-5-hydroxylase. This group of inherited metabolic diseases exhibits an autosomal recessive inheritance pattern. Without early treatment with a Phe-restricted diet, it leads to progressive neurodevelopmental delay, which can result in intellectual impairment, skin and hair depigmentation, failure to thrive, characteristic urine odor, eczema and epilepsy.[1-11]

HPAs are the second most common cause of preventable intellectual impairment and include several conditions that differ clinically and biochemically, with phenylketonuria (PKU) being the most common and severe. Differential diagnosis of HPA is critical for determining correct treatment.[1,4,5] PKU frequency ranges from $1 / 143,000$ live births in Japan to $1 / 10,000$ in Northern Europe, with 1/4500 in Ireland and 1/2600 in Turkey.[2] Incidence in Cuba has been reported as 1/50,000 live births (1989)[3] and $1 / 52,590$ (2007).[10] reverse-phase HPLC with direct fluorescence), hyperphenylalaninemia classification, year of diagnosis, sex, and province of origin.

RESULTS Of the samples, $97.7 \%$ (519/531) were confirmed as false positives, and $10.4 \%(55 / 531)$ had transient neonatal tyrosinemia. Hyperphenylalaninemia was diagnosed in 12 infants (2.2\%): $1.3 \%$ (7/531) presented classical PKU, with $34.7 \pm 14.7 \mathrm{mg} / \mathrm{dL}$ phenylalanine in serum and phenylalanine/tyrosine ratio of $18.9 \pm 12.7$; and $0.9 \%(5 / 531)$ had persistent hyperphenylalaninemia, with $8.9 \pm 3.4$ $\mathrm{mg} / \mathrm{dL}$ of phenylalanine and phenylalanine/tyrosine ratio of $4.5 \pm 1.6$. Matanzas Province contributed more cases than any of Cuba's 14 other provinces $(3 / 12,25 \%)$ and there was a slight predominance of male sex $(7 / 12,58.3 \%)$. During biochemical monitoring, $83.3 \%$ of patients $(10 / 12)$ reduced their levels of phenylalanine $(\leq 5 \mathrm{mg} / \mathrm{dL}$ or $300 \mu \mathrm{mol} / \mathrm{L})$ : 5 with classical PKU and all 5 with persistent hyperphenylalaninemia. The incidence of neonatal hyperphenylalaninemias was $1 / 22,503$ live births and 1/38,577 for classical PKU.

CONCLUSIONS HPLC for simultaneous quantification of phenylalanine and tyrosine in serum meets the needs of a confirmatory test for patients testing positive in Cuba's National Neonatal Screening Program for Phenylketonuria (which has high false positive rates). It has enabled introduction in Cuba of a second PKU diagnostic criterion of positivity for both the classification of hyperphenylalaninemias and the biochemical monitoring of diagnosed patients.

KEYWORDS Hyperphenylalaninemias, phenylketonuria, phenylalanine hydroxylase deficiency disease, HPLC, phenylalanine, tyrosine, $\mathrm{PKU}, \mathrm{PAH}$ deficiency, $\mathrm{BH} 4$ deficiency, genetic disease, hereditary disease, screening, Folling disease, Cuba
In 1984, neonatal PKU screening began in Havana, using dried blood samples on filter paper to measure Phe concentration with the Guthrie and Susi bacterial inhibition test.[12] This screening program was expanded to the rest of Cuba in 1986,[13] as part of the National Neonatal Screening Program (PNPN). It has facilitated earlier detection of HPA and dietary treatment, and has helped reduce occurrence of intellectual impairment in these patients. [14] In 2000, the PNPN began to use domestic technology for HPA diagnosis, the SUMA ultramicroanalytical system and its UMTEST-PKU reagent kit.[15]

Until 2010, HPA confirmatory diagnosis in Cuba was done with spectrofluorimetry to quantify Phe serum levels only, the first of two diagnostic criteria, since the lack of high-pressure liquid chromatography technology (HPLC) prevented us from introducing the second criterion, the Phe/Tyr ratio, which reduces false positive results and is the most commonly used worldwide for differential diagnosis and biochemical monitoring.[7,16] HPLC is the most widely used quantitative screening method for diagnosing inborn errors of metabolism, chosen for its speed and specificity, and because it permits simultaneous quantification of several biochemical markers using small sample volumes.[1,17-26]

In the first semester of 2010, the National Medical Genetics Center (CNGM) in Havana validated an isocratic reverse-phase 
HPLC method with direct fluorescent detection for simultaneous quantification of Phe and Tyr in serum, according to modifications of the method described by Kandar and Zakova.[26] It was introduced in the second half of that year for confirmatory and differential HPA diagnosis, as well as for biochemical monitoring of diagnosed patients under dietary treatment.[27,28]

The aim of this study was to describe the first two years' experience after introducing HPLC for both confirmatory diagnosis of PKU-positive cases detected by PNPN and biochemical monitoring of patients undergoing dietary treatment.

\section{METHODS}

Study type and universe A descriptive retrospective study of a series of confirmed HPA cases based on administrative data was carried out at CNGM from June 2010 through June 2012. The universe consisted of 531 infants who tested PKU-positive (Phe $>4$ $\mathrm{mg} / \mathrm{dL}$ or $240 \mu \mathrm{mol} / \mathrm{L}$ ), from a total of 270,041 newborns screened in the PNPN (70\% of total live births n 2010-2012).[29] Infants' serum samples were received at CNGM for confirmatory diagnosis and subsequent biochemical monitoring of cases diagnosed, both by HPLC.

\section{Variables}

Phe and Tyr serum concentration and Phe/Tyr concentration ratio For HPLC confirmatory diagnosis of HPA, laboratory cutoff points were determined for the two diagnostic criteria: first criterion, serum Phe of $4 \mathrm{mg} / \mathrm{dL}(240 \mu \mathrm{mol} / \mathrm{L})$; and second criterion Phe/Tyr = 2; higher values were considered pathological.[27,28] For diagnosis of transient neonatal tyrosinemia (TNT), the reference interval determined for serum Tyr levels was $0.9-1.4 \mathrm{mg} / \mathrm{dL}(50-77 \mu \mathrm{mol} / \mathrm{L})$ and for the Phe/Tyr ratio, 0.5-1.7; Tyr concentrations $>1.4 \mathrm{mg} / \mathrm{dL}$ and Phe/Tyr ratios $<0.5$ were considered pathological.[30]

HPA classification The literature describes different criteria for HPA classification (serum Phe, dietary Phe tolerance and enzyme activity).[1,4-9] In this paper, only Phe levels, assessed in serum during diagnostic confirmation, were considered. HPAs were classified as:

- transient HPA, if Phe $>4-10 \mathrm{mg} / \mathrm{dL}$

(>240-600 $\mu \mathrm{mol} / \mathrm{L})$ and only in the neonatal period;

- persistent HPA, if Phe $>4-16.6 \mathrm{mg} / \mathrm{dL}$ (>240-1000 $\mu \mathrm{mol} / \mathrm{L})$; and

- $\mathrm{PKU}$, if Phe $>16.6 \mathrm{mg} / \mathrm{dL}(>1000 \mu \mathrm{mol} / \mathrm{L})$.

Other variables Sex, province of origin and year of HPA diagnosis.

\section{CNGM laboratory methods}

Sample collection and transportation Patients identified as HPA positive by the PNPN have $2 \mathrm{~mL}$ of peripheral blood extracted at their corresponding Provincial Medical Genetics Centers for confirmatory diagnosis. Then $2 \mathrm{~mL}$ of peripheral blood are extracted monthly from confirmed PKU patients for biochemical monitoring; the serum samples, frozen at $-20^{\circ} \mathrm{C}$, are sent to CNGM for HPLC analysis.

Sample preparation for HPLC quantification A deproteinization pretreatment is carried out, using a solution of $10 \%$ trichloroacetic acid $(1: 1, v / v)$. Samples are centrifuged for 10 minutes at $3000 \mathrm{~g}$ and the supernatant is transferred to a clean vial. Subsequently, $100 \mu \mathrm{L}$ of supernatant are transferred to the glass vial of an autoinjector; 400 $\mu \mathrm{L}$ of distilled water are added, and homogenized in a tube shaker. Phenylalanine and tyrosine quantification by HPLC Isocratic reverse-phase HPLC is used for simultaneous quantification of phenylalanine and tyrosine in serum with direct fluorescence detection, based on the method described by Kandar and Zakova,[26] modified and validated at CNGM. The method meets acceptance criteria for validation parameters established for chromatographic bioanalytical methods: specificity for simultaneous quantification of Phe and Tyr (3.5 min retention time for Tyr and 5 min for Phe), without interference from endogenous serum components; linearity in the range of concentrations studied $(0.4-18$ $\mathrm{mg} / \mathrm{dL}$ or $22-990 \mu \mathrm{mol} / \mathrm{L}$ for $\mathrm{Tyr}$ and $1-24 \mathrm{mg} / \mathrm{mL}$ or $60-1440$ $\mu \mathrm{mol} / \mathrm{L}$ for Phe); accuracy (100\% recovery for both amino acids and variation coefficients lower than 15\%); and precision (repeatability and intermediate precision with variation coefficients $<15 \%$ ). [unpublished laboratory data]

A Prominence HPLC system (Shimadzu, Japan) is used, equipped with DGU-20AS degasser, LC-20AT quaternary pump, SIL-20A autoinjector, CTO-20AC oven, RF-10AXL fluorescence detector and CBM-20A communication module. The LC Chromatography Data System Solutions program (Shimadzu, Japan) is used for data acquisition and processing. An isocratic reverse-phase technique with direct fluorescent detection $\left(\lambda_{\mathrm{Ex}}\right.$ : $260 \mathrm{~nm} ; \lambda_{\mathrm{Em}}: 282 \mathrm{~nm}$ ) is used for simultaneous quantification of both amino acids in serum.

The mobile phase consists of a mixture of absolute ethanoldistilled water in 5:95 (v/v) ratio. All determinations are performed at $30{ }^{\circ} \mathrm{C}$, in duplicate, using a Shim-pack ODS-GHRS $4 \mathrm{~mm} \times 1 \mathrm{~cm}$ pre-column and Shim-pack CLC-ODS $15 \mathrm{~cm}, 5$ $\mu \mathrm{m}$ column (Shimadzu, Japan). Work is carried out with a flow of $1 \mathrm{~mL} / \mathrm{min}$ and injection volume of $20 \mu \mathrm{L}$. Sample quantification relies on Phe and Tyr calibration curves prepared in serum with concentration range of $0.4-20 \mathrm{mg} / \mathrm{dL}$ and $1-18 \mathrm{mg} / \mathrm{dL}$, respectively, using Phe and Tyr standards (Merck, Germany).

Biochemical monitoring of diagnosed patients Monitoring is conducted in patients confirmed as positive with the sole aim of quantifying Phe. PKU patients are monitored after initiation of dietary treatment-consisting of a Phe-restricted diet to reduce elevated serum Phe to $5 \mathrm{mg} / \mathrm{dL}$ or $300 \mu \mathrm{mol} / \mathrm{L}$, and maintain these levels over the first 5 years of life,[31] for adequate growth and neurodevelopment, avoiding irreversible intellectual impairment.[1,4,8,31-35] Samples for biochemical monitoring are obtained weekly (in specialized consultations in the patients' respective Provincial Medical Genetics Centers) until metabolic compensation is reached, and monthly thereafter. Although patients diagnosed with persistent HPA are not treated, they undergo monthly biochemical monitoring until aged 12 months to rule out possible clinical manifestations; if Phe levels $>10 \mathrm{mg} / \mathrm{dL}(600 \mu \mathrm{mol} / \mathrm{L})$ appear, dietary treatment is started to prevent neurological damage. Patients with HPA are considered biochemically controlled and without risk of complications associated with low Phe (characteristic in malnutrition) when serum Phe levels are approximately $5 \mathrm{mg} / \mathrm{dL}$ (300 $\mu \mathrm{mol} / \mathrm{L}) \cdot[8,16,36,37]$

Data analysis Percentages were calculated and data grouped by diagnosis, sex, year, and province of origin. The STATISTICA 6.0 program was used to analyze data collected and to create patients' biochemical monitoring graphs, HPA and PKU incidence (number of patients/number of live births occurred during the study period for denominator). 
For biochemical monitoring, only data from the first assessments conducted until metabolic control was achieved were used; these were considered sufficient to demonstrate the usefulness of the method for our objectives.

Ethics Patient anonymity was maintained during data processing. The study and the publication of its results were approved by the CNGM ethics committee.

\section{RESULTS}

Initially, 13 infants were confirmed with HPA (2.4\%); 7 with PKU $(1.3 \%)$ and 6 with persistent HPA (1.1\%) (Table 1). One male infant from Holguín Province had persistent HPA in 2010. However, since analysis of the third sample from this patient (who was already beyond the neonatal period and without dietary treatment) showed phenylalanine concentration $<4 \mathrm{mg} / \mathrm{dL}$ and Phe/Tyr ratio $<2$, he was diagnosed as transient HPA (Table 1). Therefore, only 12 truly positive patients $(2.2 \%)$ were finally diagnosed. All remaining cases (519/531) were false positives (97.7\%) for HPA; transient neonatal tyrosinemia was detected in $10.3 \%(55 / 531)$. PKU was diagnosed in $58.3 \%$ of positive cases $(7 / 12)$, or $1.3 \%$ of the total $(7 / 531)$ (Table 2).

Table 1: Infants diagnosed with HPA by year in Cuba $(n=13)$

\begin{tabular}{|r|r|r|r|r|} 
Year & $\begin{array}{c}\text { Screen } \\
\text { +ve }^{\mathrm{a}}\end{array}$ & $\begin{array}{c}\text { PKU } \\
\text { diagnosed }^{\mathrm{b}}\end{array}$ & $\begin{array}{c}\text { Persistent } \\
\text { HPA }^{\mathrm{c}}\end{array}$ & $\begin{array}{c}\text { Transient } \\
\text { HPA }^{\mathrm{d}}\end{array}$ \\
\hline 2010 & 5 & 4 & 0 & 1 \\
\hline 2011 & 5 & 1 & 4 & 0 \\
\hline 2012 & 3 & 2 & 1 & 0 \\
\hline Total & 13 & 7 & 5 & 1
\end{tabular}

a $\mathrm{Phe}>4 \mathrm{mg} / \mathrm{dL} \quad{ }^{\mathrm{b}} \mathrm{Phe}>16.6 \mathrm{mg} / \mathrm{dL} \quad{ }^{\mathrm{c}} \mathrm{Phe}>4.0-16.6 \mathrm{mg} / \mathrm{dL}$

dPhe $>4.0-10 \mathrm{mg} / \mathrm{dL}$, limited to neonatal period

HPA: hyperphenylalaninemia Phe: phenylalanine

Table 2: PKU screening results and HPLC-confirmed cases in Cuba, 2010-2012 ( $n=531)$

\begin{tabular}{|c|c|c|}
\hline Screen positives & $\mathbf{n}$ & $\%$ \\
\hline Received for confirmation & 531 & 100.0 \\
\hline $\begin{array}{l}\text { HPA confirmed } \\
\text { Classic PKU }{ }^{\mathrm{b}} \\
\text { Persistent HPA }\end{array}$ & $\begin{array}{r}12 \\
7 \\
5\end{array}$ & $\begin{array}{l}2.2 \\
1.3 \\
0.9\end{array}$ \\
\hline False positive $^{d}$ & 519 & 97.7 \\
\hline Transient HPA ${ }^{\mathrm{e}}$ & 1 & 0.2 \\
\hline $\mathrm{TNT}^{\mathrm{f}}$ & 55 & 10.3 \\
\hline Negative & 463 & 87.2 \\
\hline
\end{tabular}

HPA: hyperphenylalaninemias

TNT: transient neonatal tyrosinemia

a Positive PKU samples from National Neonatal Screening Program

b Serum phenylalanine $>16.6 \mathrm{mg} / \mathrm{dL}$

c Serum phenylalanine $>4-16.6 \mathrm{mg} / \mathrm{dL}$

${ }^{d} \mathrm{HPLC}$ cutoffs: phenylalanine, $4 \mathrm{mg} / \mathrm{dL}$; phenylalanine/tyrosine ratio $=2$

e Serum phenylalanine $>4-10$ ) $\mathrm{mg} / \mathrm{dL}$ (only during neonatal period)

${ }^{f}$ Phenylalanine/tyrosine ratio $<0.5$

Overall incidence of HPA at birth over the study period was 1/22,503 live births, $1 / 38,577$ live births for PKU specifically. The provinces where most HPA cases were diagnosed were Matanzas with 3 cases (2 PKU and 1 persistent HPA) and Artemisa with 2 cases (1 PKU and 1 persistent HPA). Male sex was slightly more represented (7/12) than female (5/12), 58.3\% vs. $41.7 \%$. The most diagnoses were made in 2011 with $41.7 \%$ (5/12), followed by 2010 with $33.3 \%$ (4/12) and 2012 with $25 \%$ (3/12) (Table 3).
Table 3: Phe levels and Phe/Tyr ratios in patients with HPLC-confirmed HPA in Cuba, 2010-2012 ( $n=12)$

\begin{tabular}{|c|c|c|c|c|c|}
\hline Patient & Sex & $\begin{array}{c}\text { Year of } \\
\text { diagnosis }\end{array}$ & Province & $\begin{array}{c}\text { Phenyalanine } \\
\text { (mg/dL) }\end{array}$ & $\begin{array}{l}\text { Phe/Tyr } \\
\text { ratio }\end{array}$ \\
\hline \multicolumn{6}{|c|}{ PKU (n = 7) } \\
\hline 1 & $\mathrm{~F}$ & 2010 & Villa Clara & 28.5 & 27.1 \\
\hline 2 & M & 2010 & Guantánamo & 61.8 & 36.9 \\
\hline 3 & $M$ & 2010 & Artemisa & 24.9 & 9.2 \\
\hline 4 & M & 2012 & Camagüey & 38.3 & 2.4 \\
\hline 5 & M & 2012 & Matanzas & 17.1 & 13.2 \\
\hline 6 & $\mathrm{~F}$ & 2010 & Las Tunas & 29.2 & 12.8 \\
\hline \multirow[t]{4}{*}{7} & $\mathrm{~F}$ & 2011 & Matanzas & 43.0 & 31.0 \\
\hline & & & Mean (SD) & 34.7 (14.7) & $18.9(12.7)$ \\
\hline & & & Min-max & $17.1-61.8$ & $2.4-36.9$ \\
\hline & & & $\mathrm{Cl} 95 \%$ & $21.1 ; 48.3$ & $7.2 ; 30.7$ \\
\hline \multicolumn{6}{|c|}{ Persistent HPA $(n=5)$} \\
\hline 8 & M & 2011 & Pinar del Río & 7.2 & 2.1 \\
\hline 9 & M & 2011 & Cienfuegos & 5.3 & 4.6 \\
\hline 10 & $\mathrm{~F}$ & 2011 & Santiago de Cuba & 7.2 & 4.0 \\
\hline 11 & M & 2011 & Matanzas & 13.6 & 5.8 \\
\hline \multirow[t]{4}{*}{12} & $\mathrm{~F}$ & 2012 & Artemisa & 11.0 & 6.1 \\
\hline & & & Mean (SD) & $8.9(3.4)$ & $4.5(1.6)$ \\
\hline & & & Min-max & 5.3-13.6 & $2.1-6.1$ \\
\hline & & & $\mathrm{Cl} 95 \%$ & $4.7 ; 13.0$ & $2.5 ; 6.5$ \\
\hline
\end{tabular}

Phe: phenylalanine HPA: hyperphenylalaninemia Tyr: tyrosine HPLC cutoffs for positive diagnosis: phenylalanine $>4 \mathrm{mg} / \mathrm{dL}$ or $240 \mu \mathrm{mol} / \mathrm{L}$, phe/tyr ratio $>2$

In PKU patients, mean serum Phe was $34.7 \mathrm{mg} / \mathrm{dL}$ (SD 14.7) and the mean Phe/Tyr ratio was 18.9 (SD 12.7), much higher than those of patients with persistent hyperphenylalaninemia (Table 3). Biochemical monitoring found a substantial decrease and control of serum Phe levels in 10 of 12 HPA patients (83.3\%) (Figure 1).

\section{DISCUSSION}

Introduction of HPLC confirmatory of HPA diagnosis revealed high numbers of false-positive patients detected in the PNPN, which has led to performance of confirmatory diagnosis in an excessive number of samples.

PNPN methods for PKU screening may play a role in the high percentage of false positives, both the technique itself and the cutoff level chosen. It is essential to review the cutoff point chosen, since a low threshold may significantly increase the number of false positives.[15,38,39]

The problem could also be related to the low specificity of the technique, whereby an increase in the levels of Phe could be associated with an increase in Tyr.[1,37] For future PNPN screening, more advanced screening technology should be considered, such as tandem mass spectrometry, which provides greater analytic efficiency and speed, high sensitivity, high specificity and low detection limit $(1 \mathrm{nmol} / \mathrm{mL})$. The false positive rate using this technique is very low $(0.2 \%)$, and it allows simultaneous quantification of Phe, Tyr and computation of the Phe/Tyr ratio, permitting screening for large numbers of inborn errors of metabolism in the same specimen.[1,21,36,40]

False positives can also be due to other related factors, such as incorrect blood extraction or failure of patients to fast before collection. To reduce false positive PKU rates, PNPN must continue systematic training of the staff collecting the samples, since incor- 
Figure 1: Biochemical monitoring profiles of hyperphenylalaninemias patients in Cuba, 2010-2012 $(n=12)$

a: With PKU $(n=7)$
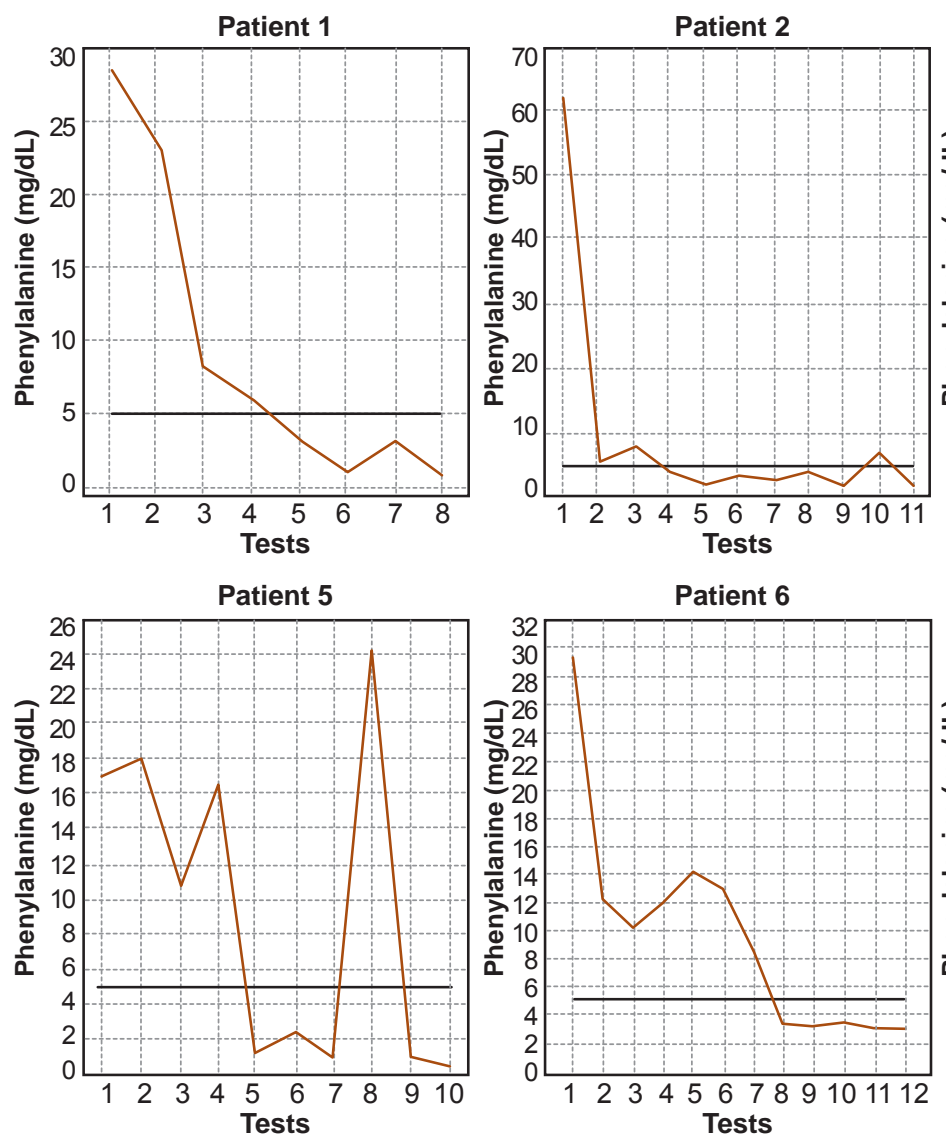

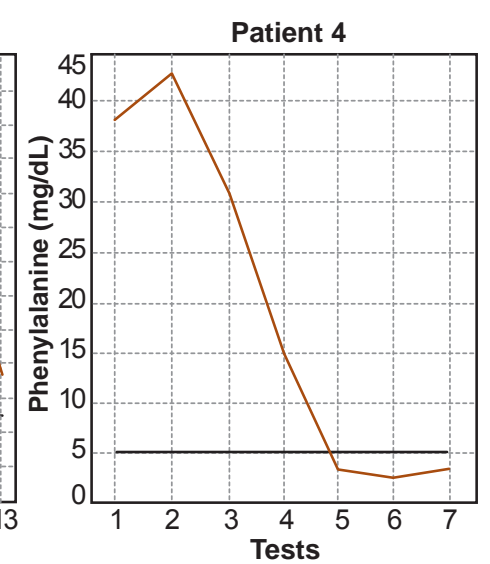

b: With persistent hyperphenylalaninemia $(n=5)$
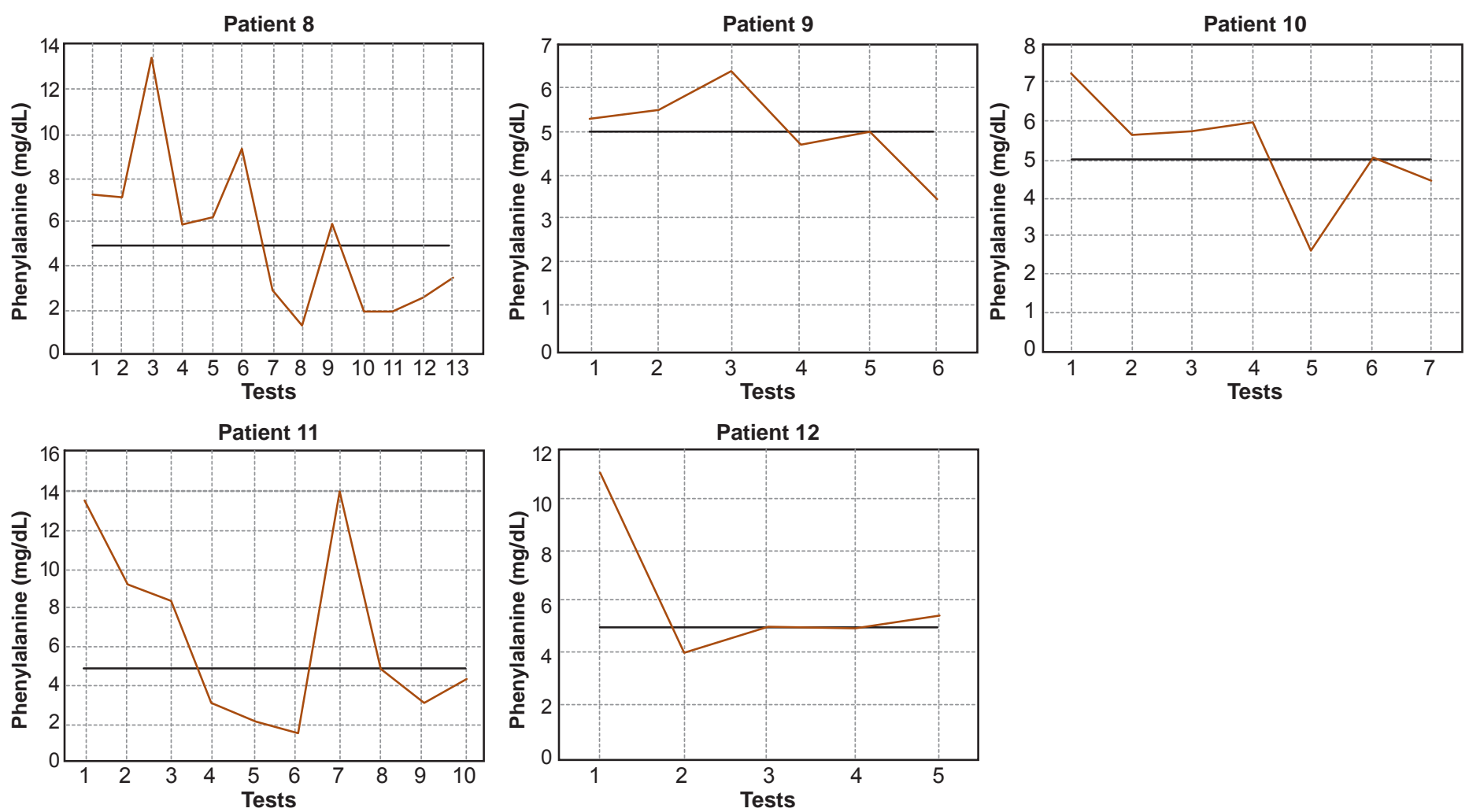
rect collection of dried blood samples on filter paper may cause both false positive and false negative results.[12,13,21,36,37,41]

It is important to record the timing and conditions of sampling on the test requisition. Sample collection immediately after breastfeeding, or improper collection of dried blood samples on filter paper could lead to false positive results. Other factors regarding blood sample collection could also be involved, such as application of more than one drop of blood from the heel in the circle of the collection card, card contamination, or samples collected later in the newborn period, when the newborn's protein intake is higher. Phe concentration in newborns may be normal until the fourth day of life but increase rapidly when protein intake begins or in those infants who receive mixed feeding.[37,42,43] This is the main reason most PKU screening programs use neonatal samples from the fifth to the seventh days of life.[44]

Detecting infants who were false positive for PKU in the PNPN owing to TNT was possible because the HPLC method allows simultaneous quantification of Phe and Tyr. Risk factors for TNT include prematurity, hyper-protein diet (mixed feeding) and deficiency of vitamin C. In studies carried out in newborns, TNT occurs between $0.2 \%$ and $10 \%$, predominating in premature infants because of an impairment or immaturity of the liver enzyme p-hydroxyphenylpyruvate oxidase, caused by variations in its formation in the perinatal period. Unlike tyrosinemia types I and II, the transient variant is asymptomatic in most cases.[45-47] For infants who tested positive for TNT, the CNGM clinical laboratory requested that geneticists in each province send a second serum sample to confirm whether it was TNT or another type of tyrosinemia. In the latter case, the patient is followed up clinically to determine whether clinical signs characteristic of each variant (Type I and II) appear; none of the infants assessed proved to have either type of tyrosinemia.

Biochemical monitoring of PKU patients is essential for enabling timely and personalized dietary treatment, thus reducing the risk of complications associated with low Phe, characteristic of malnutrition. $[1,8,16,35]$ The method applied is critical because it shows significant reduction in Phe levels to about $5 \mathrm{mg} / \mathrm{dL}(300 \mu \mathrm{mol} / \mathrm{L})$, as seen in this study. Phe decrease to the indicated values promotes the infant's adequate growth and neurodevelopment, avoiding onset of irreversible intellectual impairment.[1,5,8,16,31,36] In only two PKU patients ( 3 and 7 ) was optimal metabolic control not achieved; one (7) had just begun dietary treatment at the time of the study and had had only three Phe serum determinations. Since the laboratory does not conduct clinical care, the causes for failure to control Phe in patient 3 are unknown. The results of our assessment, however, allow us to consider that HPLC provides reliable information on the outcome of early dietary treatment, which proved to be effective in most patients assessed.

PKU incidence at birth was higher than previously reported in the Cuban population. $[3,10]$ In this study, an increase in the incidence of PKU was observed when compared to that reported with the use of the fluorimetric method.[3] This increase may be associated with introduction of a more sensitive and specific method such as HPLC, and also with introduction of the second criterion for confirmatory diagnosis and/or classification of HPA. Reducing false positives has unquestionably improved diagnosis. In Latin America, only four countries have newborn screening programs with $>20$ years of experience and $>98 \%$ coverage: Uruguay (99.5\%), Cuba (99\%), Chile (98.5\%), and Costa Rica (98.3\%). Prior to the implementation of HPLC, Cuba had the lowest PKU incidence reported in the region, specifically, 1:52,590 (2007), compared to $1: 20,891$ in Uruguay (2010), 1:19,566 in Chile (2010), and 1:49,176 in Costa Rica (2010).[10] Available data from these neonatal screening programs show the average incidence of PKU to be 1:23,518 and persistent HPA 1:20,759. [48] Incidence in European countries varies between 1:5000 and $1: 15,000 \cdot[49]$

In our study, mean Phe levels and Phe/Tyr ratios of PKU patients were four times higher than those of patients with persistent HPA. This was expected, and consistent with reports from the literature, because of the absence of enzyme phenylalanine hydroxylase activity in patients with PKU, the HPA variant with greatest negative impact on neurodevelopment.[1,4,5,7,8]

One study limitation is related to cases diagnosed with TNT, as it was not possible to establish whether patients were premature newborns, since the confirmatory HPA test requisition does not collect this data. Even with its limitations, however, this study provides insight into the performance of PNPN's PKU screening program. The results have been applied in PNPN, informing program managers as they analyze the various stages in the process and identify problems that need correcting.

\section{CONCLUSIONS}

HPLC for simultaneous quantification of phenylalanine and tyrosine in serum provides a necessary addition to PKU screening by PNPN for more accurate confirmation of positivity in patients. It has enabled the introduction in Cuba of a second PKU diagnostic criterion of positivity for both classification of hyperphenylalaninemias and biochemical monitoring of diagnosed patients. - 1 -

\section{REFERENCES}

1. Belmont-Martínez L, Fernández-Lainez $C$, Ibarra-González I, Guillén-López S, MonroySantoyo S, Vela-Amieva M. Evaluación bioquímica de la fenilcetonuria (PKU): del diagnóstico al tratamiento. Acta Pediatr Méx. 2012 NovDec;33(6):296-300. Spanish.

2. Mitchell JJ. Phenylalanine Hydroxylase Deficiency. In: Pagon RA, Adam MP, Bird TD, editors. GeneReviews $^{\mathrm{TM}}$ [Internet]. 2010 Jan 10 [updated 2013 Jan 31; cited 2014 Jan]. Seattle (WA): University of Washington; 1993-2014. Available from: http://www.ncbi.nlm.nih.gov/books/ NBK1504/

3. Gutiérrez García E, Barrios García B, Damiani Rosell A. Estudio de prevalencia de la fenilcetonuria en una muestra de niños con retraso mental. Rev Cubana Ped. 1989;61(1):94-8. Spanish.

4. Scriver C, Kaufman S. The hyperphenylalaninemias. In: Scriver C, Beaudet AL, Sly WS, Barton C, Valle D, Kinsler KW, et al, editors. The metabolic and molecular bases of inherited disease. 8th ed. Vol II. New York: McGraw-Hill; 2001. p. 1667-724.

5. Cornejo V, Raimann E. Errores innatos del metabolismo de los aminoácidos: Hiperfenilalaninemias. In: Colombo M, Cornejo V, Raimann $\mathrm{E}$, editors. Errores innatos en el metabolismo del niño. 1st ed. Santiago de Chile: Editorial Universitaria; 1999. p. 59-65. Spanish.
6. Smith I, Philip L. The hyperphenylalaninemias. In: Fernandes J, Saudubray JM, Van den Berghe $\mathrm{G}$, editors. Inborn metabolic diseases, diagnosis and treatment. 3rd ed. Heidelberg (DE): Springer-Verlag; 2000. p. 171-83.

7. Martínez Rey L. Las Hiperfenilalaninemias. Recomendaciones para el Genetista Clínico. Havana: Editorial Ciencias Médicas; 2006. 49 p. Spanish.

8. Ramírez-Farías MC, Pérez-Andrade ME, Ibarra-González I, Vela-Amieva M. Controversias en la clasificación de las hiperfenilalaninemias. Propuesta de unificación. Acta Ped Méx. 2007;28(6):261-9. Spanish.

9. Marcos Plasencia LM, Pérez Torres AJ, González Cabrera B, Tamayo Chong V. Actuali- 
dad de la fenilcetonuria en Cuba. Avances Méd Cuba. 2002;33:12-6. Spanish.

10. Borrajo G. Panorama epidemiológico de la fenilcetonuria en Latinoamérica. Acta Ped Méx. 2012;33(6):279-87. Spanish.

11. Cornejo V, Manríquez V, Colombo M, Mabe $P$, Jiménez $M$, de la Parra $A$, et al. Fenilcetonuria diagnosticada en período neonatal y lactancia materna. Rev Méd Chile. 2003 Nov;131(11):1280-7. Spanish.

12. Guthrie R, Susi A. A simple phenylalanine method for detecting phenylketonuria in large populations of newborn infants. Pediatrics. 1963 Sep;32:338-43.

13. Heredero L, Atencio G, Vega JL, Gutiérrez E, Damiani A. Diagnóstico precoz de fenilcetonuria en Cuba. Rev Cuba Pediatr. 1986 JanFeb;58(1):27-33. Spanish

14. Martínez Rey L, Robaina Jiménez Z, García Izquierdo S, Gutiérrez García E. Resultados Clínico-Sociales del Programa Cubano de Pesquisa Neonatal de Fenilcetonuria durante 20 años. Rev Cub Genet Comun [Internet]. 2008 Jan-Apr [cited 2014 Aug 10];2. Available from: http://bvs.sld.cu/revistas/rcgc/v2n1/ rcgc07108\%20.htm. Spanish.

15. TecnoSuma Internacional, S.A. UMTEST ${ }^{\circledR}$ PKU [Internet]. Havana: Immunoassay Center (CU); 2004 Apr 20 [cited 2014 Mar 10]. 11 p. Available from: http://www.tecnosuma.com/ Informacion/Inserts \%20(PDF)/UMTEST\%20 PKU.pdf. Spanish.

16. Singh R, Rohr F, Frazier D, Cunningham A, Modifi S, Ogata B, et al. Recommendations for the nutrition management of phenylalanine hydroxylase deficiency. Genetics Med. 2014 Feb;16(2):121-31.

17. Drnevich D, Vary TC. Analysis of physiological amino acids using dabsyl derivatization and reversed-phase liquid chromatography. J Chromatogr. 1993 Mar 5;613(1):137-44.

18. Madira WM, Xavier F, Stern J, Wilcox AH, Barron $\mathrm{JL}$. Determination and assessment of the stability of phenylalanine and tyrosine in blood spots by HPLC. Clin Chem. 1992 Oct;38(10):2162-3.

19. Kok WT, Brinkman UA, Frei RW. Rapid determination of phenylalanine and tyrosine in urine and serum by HPLC with electrochemical detection. J Pharm Biomed Anal. 1983;1(3):369-72.

20. Malaver Ortega LF, Alméciga-Díaz CJ, Morales Monsalve IS, Echeverri Peña OY, Guevara Morales J, Zuluaga Torres E, et al. Cuantificación de aminoácidos en plasma empleando Cromatografía Líquida de Alta Eficiencia. Acta Bioquím Clín Latinoam. 2009 Oct-Dec;43(4):647-61. Spanish.

21. Chace DH, Millington DS, Terada N, Kahler SG, Roe CR, Hofman LF. Rapid diagnosis of phenylketonuria by quantitative analysis for phenylalanine and tyrosine in neonatal blood spots by tandem mass spectrometry. Clin Chem. 1993 Jan;39(1):66-71.

22. Qu Y, Slocum R, Fu J, Rasmussen WE, Rector $\mathrm{HD}$, Miller JB, et al. Quantitative amino acid analysis using a Beckman system gold HPLC 126AA analyzer. Clin Chim Acta. 2001 Oct;312(12):153-62.

23. Bartolomeo MP, Maisano F. Validation of a reversed-phase HPLC method for quantitative amino acid analysis. J Biomol Tech. 2006 Apr;17(2):131-7.

24. Frank MP, Powers RW. Simple and rapid quantitative high-performance liquid chromatographic analysis of plasma amino acids. J Chromatogr B Analyt Technol Biomed Life Sci. 2007 Jun 1;852(1-2):646-9.

25. Gatti R, Gioia MG. Liquid chromatographic fluorescence determination of amino acids in plasma and urine after derivatization with phanquinone. Biomed Chromatogr. 2008 Feb;22(2):207-13.
26. Kandar R, Zakova P. Determination of phenylalanine and tyrosine in plasma and dried blood samples using HPLC with fluorescence detection. J Chromatography B Analyt Technol Biomed Life Sci. 2009 Nov 15;877(30):3926-9.

27. Fuentes LE, Contreras J, Alonso E, Martínez L. Punto de corte óptimo para el diagnóstico confirmatorio de hiperfenilalaninemias por HPLC. Rev Cub Gen Com [Internet]. 2014 [cited 2014 Sep 15];8(1). Available from: http://bvs.sld.cu/revis tas/rcgc/v8n1/rcgc050144.html. Spanish.

28. Contreras J, Alonso E, Fuentes LE, Gandarilla $A$. Relación fenilalanina/tirosina en niños sanos y con hiperfenilalaninemias en Cuba. Rev Cub Gen Com [Internet]. 2012 [cited 2014 Sep 15];6(2). Available from: http://bvs.sld.cu/revis tas/rcgc/v6n2/rcgc050212.html. Spanish.

29. National Health Statistics and Medical Records Division (CU). Anuarios Estadísticos de Salud 2010-2012 [Internet]. 2012 [cited 2013 Jan 15]. Available from: www.sld.cu/sitios/dne/. Spanish.

30. Contreras J, Alonso E, Camayd I, Hernández O, de la Peña D, Nogueras L. Tirosinemia neonatal transitoria: diagnóstico bioquímico de un caso. Rev Cub Gen Com [Internet]. 2012 [cited 2014 Sept 15];6(1):[about 3 screens]. Available from: http://bvs.sld.cu/revistas/rcgc/v6n1/rcgc100112 .html. Spanish

31. Campistol J, Gassió R, Artuch R, Vilaseca MA; PKU Follow-up Unit. Neurocognitive function in mild hyperphenylalaninemia. Dev Med Child Neurol. 2011 May;53(5):405-8.

32. Blau N, van Spronsen FJ, Levy HL. Phenylketonuria. Lancet. 2010 Oct 23;376(9750):1417-27.

33. Arcos-Correa JH, Vela-Amieva M. El paciente adulto con fenilcetonuria: un nuevo reto para el médico internista en México. Med Int Mex. 2012 May-Jun;28(3):256-61. Spanish.

34. Vela Amieva M, Ibarra González I, Monroy Santoyo S, Fernández Laínez C, Guillén López S, Belmont Martinez L, et al. Modelo de atención inicial de la fenilcetonuria y otras hiperfenilalaninemias en el Instituto Nacional de Pediatría. Acta Pediatr Méx. 2010 Nov-Dec;31(6):297-303. Spanish.

35. Marcos Plasencia LM. Soporte alimentario, nutrimental y metabólico de los fenilcetonúricos en Cuba [thesis]. [Havana]: University of Medical Sciences of Havana; 2010. Spanish.

36. Campos D. Tamiz de los errores innatos del metabolismo por espectrometría de masas en tándem: principales biomarcadores. Rev Méd Chile. 2011 Oct;139(10):1356-64. Spanish.

37. A Laboratory Guide to Newborn Screening in the UK for phenylketonuria [Internet]. London: Public Health England; 2011 Apr 4 [cited 2013 Jan 15]. Available from: http://newbornbloodspot.screen ing.nhs.uk/pku-supportingdocs\#fileid 11844

38. Cunningham GC, Lorey F, Arnopp J, Patterson $M$, Currier R. Early discharge trends and their effect on PKU screening. In: Pass K, Levy $\mathrm{H}$, editors. Early hospital discharge: Impact on newborn screening. Council of Regional Networks for Genetics Services; March 31, 1995. Atlanta: Emory University School of Medicine; 1995. p. 31-56.

39. Marrero-González N, González-Reyes EC, Frómeta-Suárez A, Baloy-Nodarse A, CastellsMartínez E, Pérez-Morás PL, et al. Influencia de la edad en los resultados del cribado neonatal de hipotiroidismo congénito, fenilcetonuria y galactosemia. Rev Latinoamer Patol Clin. 2004 OctDec;51(4):220-5. Spanish.

40. Blau N, Hennermann J, Langenbeck U, LichterKonecki U. Diagnosis, classification and genetics of phenylketonuria and tetrahydrobiopterin (BH4) Deficiencies. Mol Genet Metab. 2011;104 Suppl:S2-9.

41. Cedillo Carvallo B, Estrada Gómez RA, Jonguitud Díaz V, Parra Ortega I. Factores que afectan algunas de las pruebas del tamiz neonatal. Med Univer. 2007 Jan-Mar;9(34):3-6. Spanish.

42. Harrison TR. Trastornos del metabolismo. Trastornos hereditarios del metabolismo de los aminoácidos. In: Braunwald E, Isselbacher KJ, Peterdosdorf RG, Wilson JD, Martin JB, Fauci AS, editors. Principios de medicina interna. 7th ed. México. D.F: Interamerican McGraw-Hill; 1989. p.1967-72. Spanish.

43. Cerone R, Caruso U, Schiaffino MC, Gazzolo A Barella C, Romano C. Early newborn screening for phenylketonuria: phenylalanine levels during the first 24 hours of life. In: Levy HL, Hermos RJ, Grady GF, editors. Proceedings of the Third Meeting of The International Society for neonatal screening; 1996 Oct 20-23; Boston, Massachusetts. New England: Regional Newborn Screening Program; 1996. p. 293-4.

44. Marrero-González N, Frometa Suárez A, Coto $\mathrm{R}$, Villegas L. Medición de TSH, T4 y Phe en muestras de sangre del cordón umbilical en papel de filtro: impacto en el tamizaje neonatal. Biomédica. 2000;20(1):33-4. Spanish.

45. Pontón RA. Errores congénitos del metabolismo: tirosinemias. INVENIO. 2004 Jun;7(12):117-26. Spanish.

46. Burgos LC, Manotas RJ. Tirosinemia neonatal. IATREIA. 1995 Dec;8(4):147-9. Spanish.

47. Scriver C, Kaufman S. Hypertyrosinemia. In: Scriver C, Beaudet A, Sly W, Valle D, editors. The metabolic and molecular bases of inherited disease. 8th ed. Vol II. New York: McGraw-Hill; 2001. p. 1777-806.

48. Torres-Sepúlveda MR, Martínez de Villareal LE, González Alanis R, Ruíz Herrera C. Tamiz metabólico neonatal por espectrometría de masas en tándem: dos años de experiencia en Nuevo León, México. Salud Pública Méx. 2008 May-Jun;50(3):200-6. Spanish.

49. Zschocke J, Haverkamp T, Birk Moller L. Clinical utility gene card for Phenylketonuria. Eur J Hum Genet [Internet]. 2012 Feb [cited 2013 Jan 14];20(2). Available from: www.nature.com/ejhg/ journal/v20/n2/full/ejhg2011172a.html

\section{THE AUTHORS}

Jiovanna Contreras Roura (Corresponding author: jcontreras@cngen.sld.cu), pharmacist with a master's degree in experimental pharmacology. Associate researcher, HPLC and aminoacid laboratory, National Medical Genetics Center (CNGM), Havana, Cuba.

Elsa Alonso Jiménez, laboratory technician specializing in HPLC, CNGM HPLC and aminoacid laboratory, Havana, Cuba.

Lisset E. Fuentes Smith, mathematician. Adjunct researcher, CNGM, Havana, Cuba.

Submitted: September 13, 2013

Approved for publication: December 10, 2014 Disclosures: None 